L. A. Boiko, L. S. Fira, N. I. Burmas, I. R. BEKuS

I. Horbachevsky Ternopil State Medical University

\title{
OXIDATIVE PROCESSES PECULIARITY IN RATS AFFECTED BY CARBON TETRACHLORIDE BASED ON MALATHION INTOXICATION
}

Topicality. The chemical pollution of environment and its impact on the human body is one of the problems not fully studied. It is a question of priority. Carbon and tetrachloride malathion are the most dangerous contaminative elements considered to be the risk factors for many environmentally dependent diseases. Therefore, it is actual to study the characteristics and mechanisms of the aforementioned xenobiotics combined action on the body.

Aim. To investigate the free radical processes activity and the endogenous markers of intoxication at the conditions of effect on the rats organism by tetrachloride bbeing affected by malathion.

Materials and methods. Experiments conducted on white rats being under carbon tetrachloride intoxication influence (4th, 7th days of the affection) on the basis of thirtieth days malathion affection. Rats were taken out of the experiment by the thiopental anesthesia.

Results and discussion. The experimental data proved the malathion and carbon tetrachloride toxic effect, which increases by the conditions of their combined using.

Conclusions. It was established, that the maximum activation of free radical processes and deepening endogenous intoxication observed on the seventh day affection by the carbon tetrachloride on on the basis of thirtieth days malathion intoxication.

Key words: carbon tetrachloride; malathion; rats; endogenous intoxication; free radical processes

\section{Л. А. Бойко, Л. С. Фіра, Н. І. Бурмас, І. Р. Бекус}

Особливості перебігу окиснювальних процесів у щурів, уражених тетрахлорометаном на тлі інтоксикації карбофосом

Актуальність. Проблема впливу хімічного забруднення навколишнього середовища на організм людини $\epsilon$ однією з пріоритетних та не до кінця вивчених. Серед забруднювачів значну загрозу становлять тетрахлорометан та карбофос - фактори ризику виникнення багатьох екологічно залежних хвороб. Тому вивчення особливостей та механізмів комбінованої дії вищевказаних ксенобіотиків на організм $є$ актуальним.

Метою роботи було дослідження активності вільнорадикальних процесів та маркерів ендогенної інтоксикації за умов впливу на організм щурів тетрахлорометану на тлі ураження карбофосом.

Матеріали та методи. Експерименти проведені на білих щурах, які піддавались інтоксикації тетрахлорометаном (4-та, 7-а доба ураження) на тлі тридцятиденного ураження карбофосом. Щурів виводили з експерименту під тіопенталовим наркозом.

Результати та їх обговорення. Експериментальні дані підтвердили токсичний вплив карбофосу та тетрахлорометану, який підвищується за умов їх комбінованого застосування.

Висновки. Встановлено, що максимальна активація вільнорадикальних процесів та поглиблення ендогенної інтоксикації спостерігаються на сьому добу ураження тетрахлорометаном на тлі тридцятиденної інтоксикації карбофосом.

Ключові слова: тетрахлорометан; карбофос; щури; ендогенна інтоксикація; вільнорадикальні процеси

\section{Л. А. Бойко, Л. С. Фира, Н. И. Бурмас, И. Р. Бекус}

Особенности протекания окислительных процессов у крыс, пораженных

\section{тетрахлорметаном на фоне интоксикации карбофосом}

Актуальность. Проблема влияния химического загрязнения окружающей среды на организм человека является одной из приоритетных и до конца не изученных. Среди загрязнителей большую угрозу представляют тетрахлорметан и карбофос - факторы риска многих экологически зависимых болезней. Поэтому изучение особенностей и механизмов комбинированного влияния вышеупомянутых ксенобиотиков на организм является актуальным.

Целью работы было изучение активности свободнорадикальных процессов и маркеров эндогенной интоксикации при воздействии на организм крыс тетрахлорметана и карбофоса.

Материалы и методы. Эксперименты проведены на белых крысах, которые подвергались интоксикации тетрахлорметаном (4-ые, 7-е сутки поражения) на фоне тридцатидневного поражения карбофосом. Крыс выводили из эксперимента под тиопенталовым наркозом.

Результаты и их обсуждение. Экспериментальные данные подтвердили токсическое влияние карбофоса и тетрахлорметана, которое усиливается при условии их комбинированного применения. Это подтверждается активацией свободнорадикальных процессов и углублением эндогенной интоксикации, максимальное развитие которой наблюдалось на седьмые сутки поражения тетрахлорметаном на фоне тридцатидневной интоксикации карбофосом.

Выводы. Доказано, что максимальная активация свободнорадикальных процессов и углубление эндогенной интоксикации наблюдались на седьмые сутки поражения тетрахлорметаном на фоне тридцатидневной интоксикации карбофосом.

Ключевые слова: тетрахлорметан; карбофос; крысы; эндогенная интоксикация; свободнорадикальные процессы 


\section{INTRODUCTION}

The study of combined effect characteristics and mechanisms of the most common xenobiotics as the main factors of the many environmentally dependent diseases development is the most perspective biology and medicine direction in the environmental pollution conditions. These toxins are organophosphorus compounds (OPs), and chlorinated hydrocarbons.

The body contamination with OPs leads to the development of the oxidative stress, which themself are significant toxicity agents $[1,2]$. OPs characterized by a high biological activity. OPs include malathion with a middle degree of toxicity.

One of the most dangerous xenobiotics are chlorinated hydrocarbons including carbon tetrachloride $\left(\mathrm{CCl}_{4}\right)$, which is quite widely used at workplaces, homes and agriculture. Carbon tetrachloride known as a classical hepatotropic poison and its toxic effects on the liver was well studied in experimental models $[3,4,5]$.

Usually it often happens the combined effect of several toxic agents, which can disrupt the balance of oxidative processes in the body and cause serious diseases.

Objective. The aim of the presented study was to investigate the free radical activity and the level of endogenous intoxication in rats under simultaneous affection of malathion and carbon tetrachloride.

\section{MATERIALS AND METHODS}

Experiments were conducted on white rats with the weight 175-200 g. The animals were kept on a standard food allowance at the vivarium of I. Horbachevsky Ternopil State Medical University. All experiments on animals were carried out in compliance with the general rules that were approved at the National Congress on Bioethics (Kiev, Ukraine 2001) and the 1-st Ukrainian National Congress on Bioethics subjected to the NIH Guide for the Care and Use of Laboratory Animals (Guide., 2011).

The animals were divided into five groups: the 1-st intact control; the 2-nd - the animals were affected with malathion for 10 days and on the 4-th day the rats were affected with tetrachloromethane, the 3-d group of animals -10 days affecting by malathion and on the 7 -th day intoxication with $\mathrm{CCl}_{4}$, the 4-th group - the rats were affected by malathion for 30 days and on the 4-th days was caused the development of tetrachloromethane hepatitis, the 5 -th group of animals - 30 days affecting with malathion and on the 7-th day affecting with $\mathrm{CCl}_{4}$.

Malathion was daily administrated intragastrically in the form of the aqueous solution of $20 \mathrm{mg} / \mathrm{kg}$ on the weight of a rat, that is equal $1 / 10$ from the $\mathrm{LD}_{50}$. Carbon tetrachloride was administrated intragastrically, twice, in a day duration in the form of $50 \%$ oil solution in the dose of $1.0 \mathrm{ml} / \mathrm{kg}$ calculated on a weight of the animal.

The rats were euthanized with sodium thiopental. The investigation objects were a blood serum, a myocardium and a liver of the animals.

The activity of the free radical processes in the rats bodies was evaluated concerning to the amount of TBAactive products in a blood serum, homogenates of myocardium and liver of the animals $[6,7]$ and the oxidation modification of protein by 2,4-Dinitrophenylhydrazine (2,4 DNPh) [8].

The level of the endogenous intoxication studied according to the content of molecules of the average weight (MAW) in a blood serum $\left(\mathrm{BM}_{1}\right.$ fraction $\left.\mathrm{BM}_{2}\right)$ [9] and the degree of damage of the erythrocyte membrane (EII) $[10,11]$.

The statistic processing of the received results were carried outby the "Statistica 6,0" with the applying of Student's $\mathrm{t}$-criterion. Results were considered significant at $\mathrm{p} \leq 0.05$.

\section{RESULTS AND DISCUSSION}

The conducted experiments showed that, after administration of xenobiotic into the rats bodies it was observed the activation of lipid peroxidation. One of the main product of LPO is TBA-AP which allowed us to judge the intensity of these processes (Tab. 1).

The content of TBA-AP increased on $42 \%$ in a blood serum, $35 \%$ - in a liver, $14 \%$ - in a myocardium after

Table 1

\section{THE CONTENT OF TBA - ACTIVE PRODUCTS IN A BLOOD SERUM ( $\mu \mathrm{mol} / \mathrm{L})$, LIVER $(\mu \mathrm{mol} / \mathrm{kg})$ AND MYOCARDIUM ( $\mu \mathrm{mol} / \mathrm{kg}$ ) OF THE RATS, AFTER COMBINED AFFECTING BY TETRACHLOROMETHANE AND MALATHION $(M \pm m ; n=30)$}

\begin{tabular}{|c|c|c|c|c|}
\hline \multirow{2}{*}{ Groups of animals } & \multicolumn{4}{|c|}{ Term of the investigation, days } \\
\hline & $10+4 \mathrm{CCI}_{4}$ & $10+7 \mathrm{CCl}_{4}$ & $30+4 \mathrm{CCl}_{4}$ & $30+7 \mathrm{CCl}_{4}$ \\
\hline \multicolumn{5}{|c|}{ The blood serum } \\
\hline Affected by the toxins & $1.31 \pm 0.02^{*}$ & $1.70 \pm 0.01^{*}$ & $2.62 \pm 0.02^{*}$ & $3.07 \pm 0.01 *$ \\
\hline \multicolumn{5}{|c|}{ The liver } \\
\hline \multicolumn{5}{|c|}{ The myocardium } \\
\hline Intact control & \multicolumn{4}{|c|}{$11.25 \pm 0.09$} \\
\hline Affected by the toxins & $12.85 \pm 0.02^{*}$ & $13.63 \pm 0.11^{*}$ & $15.64 \pm 0.05^{*}$ & $16.67 \pm 0.06^{*}$ \\
\hline
\end{tabular}

Notes: here and in the following tables * - valid changes between the intact and affected animals, $\mathrm{p} \leq 0.05$. 
CONTENT OF 2,4-DNPH IN A BLOOD SERUM AND LIVER OF THE RATS ( $\mu \mathrm{mol} / \mathrm{g}$ PROTEIN), AFTER COMBINED AFFECTING BY TETRACHLOROMETHANE AND MALATHION $(\mathrm{M} \pm \mathbf{m} ; \mathbf{n}=30)$

\begin{tabular}{|l|c|c|c|c|}
\hline \multirow{2}{*}{ Group of animals } & \multicolumn{2}{c|}{ 2,4-DNPh of the neutral character $(370 \mathrm{~nm})$} & \multicolumn{2}{c|}{ 22,4-DNPh of the basic character $(430 \mathrm{~nm})$} \\
\cline { 2 - 5 } & A blood serum & A liver & A blood serum & A liver \\
\hline Intact control & $0.120 \pm 0.005$ & $0.130 \pm 0.009$ & $0.130 \pm 0.008$ & $0.120 \pm 0.008$ \\
\hline Affected $10+4 \mathrm{CCl}_{4}$ & $0.150 \pm 0.008^{*}$ & $0.170 \pm 0.008^{*}$ & $0.170 \pm 0.009^{*}$ & $0.150 \pm 0.008^{*}$ \\
\hline Affected $10+7 \mathrm{CCl}_{4}$ & $0.150 \pm 0.010^{*}$ & $0.180 \pm 0.010^{*}$ & $0.170 \pm 0.006^{*}$ & $0.160 \pm 0.010^{*}$ \\
\hline Affected $30+4 \mathrm{CCl}_{4}$ & $0.160 \pm 0.009^{*}$ & $0.190 \pm 0.010^{*}$ & $0.180 \pm 0.006^{*}$ & $0.170 \pm 0.007^{*}$ \\
\hline Affected $30+7 \mathrm{CCl}_{4}$ & $0.180 \pm 0.009^{*}$ & $0.200 \pm 0.007^{*}$ & $0.180 \pm 0.008^{*}$ & $0.160 \pm 0.009^{*}$ \\
\hline
\end{tabular}

the administration of the toxins on the 10-th and 4-th day of affection. At ten days intoxication by malathion and on the 7-th day after the administration of carbon tetrachloride, this index increased in a blood serum on $85 \%, 41 \%$ in a liver, $21 \%$ - in a myocardium. After thirty days administration of malathion and on the 4-th day of intoxication by $\mathrm{CCl}_{4}$, the content of TBA-AP increased on $185 \%$ in a blood serum, $60 \%$ - in a liver, $39 \%$ - in a myocardium regarding to the level of the intact animals. On the 30-th and the 7-th days of the administration of toxins, the level of TBA-AP increased on $234 \%$ in a blood serum, $84 \%$ - in a liver, $48 \%$ - in a myocardium regarding to the standard.

The obtained results indicate a significant activation of lipid peroxidation in the bodies of the rats at the combined affection by malathion and carbon tetrachloride. The simultaneous administration of the toxins has a synergistic effect.

Excessive formation of ROS in the affected body by toxicants not only leads to the activation of lipid peroxidation, bus intensifies the processes of oxidative modification of proteins $[8,12]$. The study of the OMP indicators showed that a blood serum and liver of the rats after the intoxication by xenobiotics increased the level of 2,4-DNPh neutral (370 $\mathrm{nm}$ ) and basic character (430 $\mathrm{nm}$ ).

The content of 2,4-DNPh neutral in a blood serum and a liver of the affected animals increases on $25 \%$ and $31 \%$ respectively at ten days administration of malathion and on the 4-th day after the intoxication by $\mathrm{CCl}_{4}$, data indicated in Tab. 2.

A similar tendency to rising it was also observed for 2,4-DNPh basic at the affecting animals.

At ten days intoxication by malathion and on the 7-th day after the administration of carbon tetrachloride, the amount of 2,4-DNPh neutral in a blood serum increased on $25 \%, 38 \%$ - in a liver; 2,4-DNPh basic increased on $32 \%$ in a blood serum and in a liver regarding to its level in the intact animals.

After 30 days administration of malathion and on the 4-th day intoxication by $\mathrm{CCl}_{4}$ the level of 2,4-DNPh neutral increased on $33 \%$ in a blood serum, on $46 \%$ in a liver of the affected animals. In the same period the content of 2,4-DNPh basic character increased on $38 \%$ in a blood serum and on $42 \%$ in a liver.
On the 30-th and 7-th days of the intoxication by the toxins the content of 2,4-DNPh neutral character increased on $50 \%$ in a blood serum of the affected animals, on $54 \%$ in a liver. The amount of 2,4-DNPh basic character increased on $38 \%$ in a blood serum, on $33 \%$ in the liver.

At the combined affection by malathion and carbon tetrachloride it was established the activation of the free radical processes and formation of the toxic products, causing a destructive impact on bio-macromolecules, these lead to development of endogenous intoxication of the body, the level of which is evaluated by the content of MAW.

After the intoxication we observed a significant increasing of the content of fractions $\mathrm{MAW}_{1}$ (dominated by aliphatic amino acids) and $\mathrm{MAW}_{2}$ (dominated by aromatic amino acids) in a blood serum of the experimental rats during a whole experiment (Tab. 3).

On the 30-th and 7-th day of the experiments under the affecting of toxins the content of MAW $\mathrm{W}_{1}$ increased on $132 \%$ in a blood serum, the content of $\mathrm{MAW}_{2}$ increased on $96 \%$ in a blood serum, relatively to the level of the intact control.

Toxic products were formed as a result of the activation of lipid peroxidation process and the accumulation of endogenous toxins formed by ROS activity that can cause destruction of cell membranes and change their permeability $[13,14]$.

We studied the permeability of the erythrocyte membrane at combined action of the studied toxins (Tab. 4).

During the experiments it was detected the relative increasing of EII after the affecting of the rats by malathion

Table 3

\section{THE CONTENT OF THE MOLECULES OF THE AVERAGE WEIGHT (MAW) IN A BLOOD SERUM (unit/L) OF THE RATS AFTER COMBINED AFFECTING BY TETRACHLORMETHANE AND MALATHION (M $\pm \mathbf{m} ; \mathbf{n}=\mathbf{3 0})$}

\begin{tabular}{|l|c|c|}
\hline \multirow{2}{*}{ Group of animals } & $\mathrm{MCM}_{1(254 \mathrm{~nm})}$ & $\mathrm{MCM}_{2(280 \mathrm{~nm})}$ \\
\cline { 2 - 3 } & A blood serum & A blood serum \\
\hline Intact control & $0.99 \pm 0.10$ & $1.11 \pm 0.16$ \\
\hline Affected $10+4 \mathrm{CCl}_{4}$ & $1.62 \pm 0.02^{*}$ & $1.68 \pm 0.04^{*}$ \\
\hline Affected $10+7 \mathrm{CCl}_{4}$ & $1.79 \pm 0.04^{*}$ & $1.90 \pm 0.05^{*}$ \\
\hline Affected $30+4 \mathrm{CCl}_{4}$ & $2.21 \pm 0.04^{*}$ & $2.13 \pm 0.03^{*}$ \\
\hline Affected $30+7 \mathrm{CCl}_{4}$ & $2.30 \pm 0.05^{*}$ & $2.18 \pm 0.03^{*}$ \\
\hline
\end{tabular}




\section{ERYTHROCYTE INDEX OF INTOXICATION (\%) OF THE RATS AFTER COMBINED AFFECTING BY TETRACHLOROMETHANE AND MALATHION $(M \pm m ; n=30)$}

\begin{tabular}{|l|c|c|c|c|}
\hline \multirow{2}{*}{\multicolumn{1}{|c|}{ Group of animals }} & \multicolumn{4}{|c|}{ Term of the investigation, days } \\
\cline { 2 - 5 } & $10+4 \mathrm{CCl}_{4}$ & $10+7 \mathrm{CCl}_{4}$ & $30+4 \mathrm{CCl}_{4}$ & $30+7 \mathrm{CCl}_{4}$ \\
\hline Intact control & \multicolumn{4}{|c|}{$28.46 \pm 0.66$} \\
\hline Affected by the toxins & $32.45 \pm 1.16^{*}$ & $32.64 \pm 1.04^{*}$ & $41.53 \pm 0.72^{*}$ & $44.49 \pm 1.47^{*}$ \\
\hline
\end{tabular}

and carbontetrachloride. It was established that the permeability of the erythrocyte membrane highly increased and till the end of the experiment it was $16 \%$ above the norm.

Our results showed that the intoxication of the rats by carbon tetrachloride become stronger under the action of malathion on the body. Lipid and protein peroxidation processes significantly intensified that evidenced by the veritable increasing of TBA - active products and 2,4DNPh in all investigated rat's tissues.It was established that the simultaneous affection of the rats by malathion and carbon tetrachloride leads to the development of endogenous intoxication and accumulation of the high amount of endogenous toxins especially the content of molecules of the average weight that can be served as a marker for assessing the degree of intoxication in the affected body.

The obtained results indicate the toxicity effect of the mentioned xenobiotics on erythrocyte membrane, that improved by the percentage increasing of their permeability and as a result can cause the destructive influence of toxicants on the structural components of cell membranes.

\section{CONCLUSIONS}

The lipid peroxidation activation and proteins oxidative modification caused by the combined carbon tetrachloride and malathion affection on the body leads to the development of endogenous intoxication. At the same condition it was observed the veritably of increased molecules average weight content in a blood serum. Exogenous and endogenous toxins perform a destructive influence on cell membranes, including red blood cells, as evidenced by the increasing of erythrocyte index of intoxication after affecting.

Conflicts of Interest: authors have no conflict of interest to declare.

\section{REFERENCES}

1. Войтенко, Н. Г. Проблемы диагностики при интоксикации фосфорорганическими соединениями / Н. Г. Войтенко, Д. С. Прокофьева, Н. В. Гончаров // Токсикол. вестник. - 2013. - № 5. - С. 2-5.

2. Чепур, С. В. Отдаленные органофосфатные нейропатии : патогенез, профилактика и лечение / С. В. Чепур // Токсикол. вестник. 2010. - № 3. - С. 42-43.

3. Біохімічні та молекулярно-біологічні механізми хімічної загибелі клітин за ураження високотоксичними ксенобіотиками / Ю. І. Губський Є. Л. Левицький, О. В. Задорина та ін. // Буковинський мед. вісник. - 2005. - Т. 9, № 2. - С. 76-77.

4. Губский, Ю. И. Коррекция химического поражения печени / Ю. И. Губский. - К. : Здоров'я, 1989. - 168 с.

5. Характеристика острого токсического действия четыреххлористого углерода как модели окислительного стресса / Л. В. Кравченко, Н. В. Трусов, М. А. Ускова и др. // Токсикол. вестник. - 2009. - № 1. - С. 12-17.

6. Лісничук, Н. Є. Дослідження параметрів вільнорадикального окиснення та стан антиоксидної системи білих щурів з експериментальним токсичним ураженням печінки / Н. Є. Лісничук // Вісник проблем біології і медицини. - 2007. - № 2. - С. 83-85.

7. Лущак, В. І. Показники оксидативного стресу. Тіобарбітурактивні продукти і карбонільні групи білків / В. І. Лущак, Т. В. Багнюкова, О. В. Лущак // Укр. біохім. журн. - 2004. - Т. 26. - С. 136-141.

8. Дубініна, О. Ю. Окислювальний стрес і окислювальна модифікація білків / О. Ю. Дубініна // Мед. хімія. - 2001. - Т. 3, № 2. - С. 5-12.

9. Никольская, В. А. Биохимический аспект рассмотрения роли молекул средней массы в организме / В. А. Никольская, Ю. Д. Данильченко, 3. Н. Меметова // Ученые записки Таврического нац. ун-та им. В. И. Вернадского. Серия «Биология, химия». - 2013. - Т. 26 (65), № 1. - С. 139-145.

10. Влияние актопротекторов на пероксидное окисление липидов и состояние мембран эритроцитов у крыс при отравлении карбофосом / В. А. Мышкин, И. А. Гуляева, Р. Б. Ибатуллина и др. // Токсикол. вестник. - 2004. - № 3. - С. 10-13.

11. Способ диагностики эндогенной интоксикации / А. А. Тогайбаев, А. В. Кургузкин, И. В. Рикун и др. // Лаб. дело. - 1988. - № 9. - С. 22-24.

12. Губский, Ю. И. Токсикологические последствия окислительной модификации белка / Ю. И. Губский, И. Ф. Беленичев, Е. Л. Левицкий // Совр. пробл. токсикол. - 2005. - № 2. - С. 4-20.

13. Биохимические маркеры интоксикации фосфорорганическими отравляющими веществами / В. И. Шмурак, И. Д. Курдюков, А. Д. Надеев и др. // Токсикол. вестник. - 2012. - № 4. - С. 30-34.

14. Pavlov, 0. O. Effect of antihypoxant actovegin on dynamics of markers of the oxygen cascade / O. 0. Pavlov // Clin. Khir. - 2008. - Vol. 9. - P. 57-59.

\section{REFERENCES}

1. Voitenko, N. G., Prokofeva, D. S., Goncharov, N. V. (2013). Toksikologicheskii vestnik-Toxical review, 5, 2-5.

2. Chepur, S. V. (2010). Toksikologicheskii vestnik-Toxical review, 3, 42-43.

3. Hubskii, Yu. I., Levytskyi, Ye. L., Zadorina, O. V. et al. (2005). Bukovynskyi medychnyi visnyk, 9 (2), 76-77.

4. Gubskii, Yu. I. (1989). Korrektcyia khinicheskogo porazheniia pecheni. Kiev: Zdorovia, 168.

5. Kravchenko, L.V., Trusov, N. V., Uskova, M. A. et al. (2009). Toksikologicheskii vestnik - Toxical review, 1, 12-17

6. Lisnychuk, N. Ye. (2007). Visnyk problem biologii i medytsyny, 2, 83-85.

7. Lushchak, V. I., Bahniukova, T. V., Lushchak, O. V. (2004). Ukrainskii biokhimichnyi zhurnal - The Ukrainian Biochemical Journal, 26, $136-141$.

8. Dubinina, O. Yu. (2001). Medychna khimiia, 3 (2), 5-12. 
9. Nikolskaia, V. A., Danilchenko, Yu. D., Memetova, Z. N. (2013). Uchenye zapiski Tavricheskogo natcyonalnogo univetsiteta im. V. I. Vernadskogo. Seriia «Biologiia, Khimiia», 26 (65), 1, 139-145.

10. Myshkin, V. A., Guliaeva, I. A., Ibatullina, R. B. et al. (2004). Toksikologicheskii vestnik - Toxical review, 3, 10-13.

11. Togaibaev, A. A., Kurguzkin, A. V., Rykun, I. V. et al. (1988). Laboratornoe delo, 9, 22-24.

12. Gubskii, Yu. I., Belenichev, I. F., Levitckii, E. L. (2005). Sovremennye problemy toksikologii, 2, 4-20.

13. Shmurak, V. I., Kurdiukov, I. D., Nadeev, A. D. et al. (2012). Toksikologicheskii vestnik - Toxical review, 4, 30-34.

14. Pavlov, O. O. (2008). Effect of antihypoxant actovegin on dynamics of markers of the oxygen cascade. Clin Khir., 9, 57-59.

\section{Information about authors:}

Boyko L. A., c. biol. s., assistant of the Department of General chemistry, I. Horbachevsky Ternopil State Medical University.

E-mail: bojko@tdmu.edu.ua. ORCID - http://orcid.org/0000-0001-5052-5604

Fira L. S., d. biol. c., professor, head of the pharmacy department, NNI PO I. Horbachevsky Ternopil State Medical University.

ORCID - http://orcid.org/0000-0002-5325-0973

Burmas N. I., c. biol. s., assistant of the Department of General chemistry, I. Horbachevsky Ternopil State Medical University. ORCID - http://orcid.org/0000-0002-8553-7434

Bekus I. R., c. biol. s., assistant professor the department of the Department of General chemistry, I. Horbachevsky Ternopil State Medical University. ORCID - http://orcid.org/0000-0002-7104-8977

Відомості про авторів:

Бойко Л. А., канд. біол. н., асистент кафедри загальної хімії, Тернопільський державний медичний університет ім. І. Я. Горбачевського.

E-mail: bojko@tdmu.edu.ua. ORCID - http://orcid.org/0000-0001-5052-5604

Фіра Л. С., д-р біол. н., професор, завідувач кафедри фармації, ННІ ПО ДВНЗ «Тернопільський державний медичний університет

iм. І. Я. Горбачевського МО3 України». ORCID - http://orcid.org/0000-0002-5325-0973

Бурмас Н. І., канд. біол. н., асистент кафедри загальної хімії, Тернопільський державний медичний університет ім. І. Я. Горбачевського.

ORCID - http://orcid.org/0000-0002-8553-7434

Бекус I. Р., канд. біол. н., доцент кафедри загальної хімії, Тернопільський державний медичний університет ім. І. Я. Горбачевського.

ORCID - http://orcid.org/0000-0002-7104-8977

Сведения об авторах:

Бойко Л. А., канд. биол. н., ассистент кафедры общей химии, Тернопольский государственный медицинский университет

им. И. Я. Горбачевского. E-mail: bojko@tdmu.edu.ua. ORCID - http://orcid.org/0000-0001-5052-5604

Фира Л. С., д-р биол. н., профессор, заведующая кафедрой фармации, УНи ПО «Тернопольский государственный медицинский университет им. И. Я. Горбачевского МЗ Украины». ORCID - http://orcid.org/0000-0002-5325-0973

Бурмас Н. И., канд. биол. н., ассистент кафедры общей химии, Тернопольский государственный медицинский университет им. И. Я. Горбачевского. ORCID - http://orcid.org/0000-0002-8553-7434

Бекус И. Р., канд. биол. н., доцент кафедры общей химии, Тернопольский государственный медицинский университет

им. И. Я. Горбачевского. ORCID - http://orcid.org/0000-0002-7104-8977

Рекомендовано д. біол. н., професором В. М. Кравченко Надійшла до редакції 18.02.2017 р 